This item was submitted to Loughborough's Research Repository by the author.

Items in Figshare are protected by copyright, with all rights reserved, unless otherwise indicated.

\title{
'OccupyBufferZone': practices of borderline resistance in a space of exception
}

\section{PLEASE CITE THE PUBLISHED VERSION}

http://dx.doi.org/10.1111/area.12005

\section{PUBLISHER}

(C) The Author. Area (c) Royal Geographical Society (with the Institute of British Geographers)

\section{VERSION}

AM (Accepted Manuscript)

\section{PUBLISHER STATEMENT}

This work is made available according to the conditions of the Creative Commons Attribution-NonCommercialNoDerivatives 4.0 International (CC BY-NC-ND 4.0) licence. Full details of this licence are available at: https://creativecommons.org/licenses/by-nc-nd/4.0/

\section{LICENCE}

CC BY-NC-ND 4.0

\section{REPOSITORY RECORD}

Antonsich, Marco. 2019. "'occupybufferzone': Practices of Borderline Resistance in a Space of Exception". figshare. https://hdl.handle.net/2134/16092. 


\title{
'OccupyBorderZone' -
}

\section{Practices of borderline resistance in a space of exception}

\author{
Marco Antonsich \\ Loughborough University, Department of Geography, Leicestershire LE11 3TU \\ M.Antonsich@1boro.ac.uk
}

Manuscript forthcoming in Area:
http://onlinelibrary.wiley.com/journal/10.1111/(ISSN)1475-4762

\section{Introduction}

On the night of October $15^{\text {th }}, 2011$ a group of about twenty young Cypriots marched in Nicosia towards the Green Line, separating the Republic of Cyprus (RoC) from the Turkish Republic of Northern Cyprus (TRNC). Shouting 'One Cyprus' and 'We want to be together' they occupied the Buffer Zone along Ledra Street, in the heart of the capital's old city centre (Figure 1). ${ }^{1}$ At the beginning, the occupation was only periodical and temporary, as protesters were gathering in the Buffer Zone only in certain days for a few hours. Starting on November $19^{\text {th }}, 2011$ the occupation became permanent, as the activists organized a small makeshift camp with sleeping and eating facilities. Over the following months, the protest gained momentum, thanks also to its visibility on various online social networks and press coverage by local, national, and international massmedia. ${ }^{2}$ Just a few days before its eviction by the GC police, on April $6^{\text {th }}, 2012$, OccupyBufferZone (OBZ) had a permanent sit-in of about 15-20 activists (who became 
60-70 at night and even more during weekends) and more than 1,000 followers on social networks. Mainly young, women and men from TRNC and RoC, not organized around any leadership and dissatisfied with the inability of their political elites to reach a solution for the reunification of the island, the OBZ activists aimed at creating a space where 'to live the solution' to the Cyprus Problem, having indeed lived together for six months in an undivided space.

Inspired by the mass protest known as 'Arab Spring' and by other world-wide Occupy movements demanding economic and social equality, OBZ has clearly been part of what Routledge and Cumbers (2009) call the Global Justice Networks (GJNs). Being a place-based movement, with a specific local agenda (namely, the reunification of Cyprus), it also articulates demands for global economic and social change.

The aim of this article is to focus on the specific spatial practices of the OBZ movement. In this sense, I join the research endeavour initiated by Paul Routledge (1994; 1996; 1998) aimed at studying the relationship between forms of resistance and places. More specifically, I am interested in the particular 'terrain of resistance' (Routledge 1994) chosen by the OBZ movement. The Buffer Zone is indeed a place where the sovereign norm produced and enforced by the two states (RoC and TRNC) is suspended. Drawing on Constantinou's (2008) post-colonial re-reading of Agamben's (1998; 2005) state of exception, I argue that it is exactly this suspension of the sovereign norm which makes resistance possible. People gathering in the Buffer Zone are no longer subjects to the hegemonic norm of their respective states and make use of this exceptionality deliberately, as a way to re-write their ethnic, cultural, and political belonging. It is exactly this voluntary act of entering a space/state of exception which gives voice and 
visibility to their political claims, aimed at overthrowing the sovereign norm which they are escaping. In this sense, I concur with Constantinou (2008) and argue that, under certain circumstances, it is possible to think that a state of exception might become a condition of empowerment rather than mere dispossession and annihilation. Yet, one should also be careful not abstracting or idealizing this state of exception. The final eviction of OBZ activists reveals indeed the existence of 'exceptions to the exception' (Constantinou, 2008) through which the sovereign reinstalls a territorializing logic of power.

I start my investigation by first offering a short overview of the Cyprus Problem and by discussing the specifics of the Buffer Zone and its exceptional status. I then analyse the OBZ movement and its practices of resistance, by mapping the multiscalar articulation of their protest, the performative use of the space they occupy, and the counter-exceptions aimed at 'normalizing' the exception when such exception does not respond anymore to the interests of the powers involved. ${ }^{3}$ I conclude by highlighting a series of theoretical considerations which, prompted by the specific experience of the OBZ movement, can elucidate further the notion of terrain of resistance.

\section{The Cyprus problem}

When in 1960 Cyprus gained its independence from the British colonial rule, the two major communities of the island - Greek Cypriots (GCs) and Turkish Cypriots (TCs) - had already developed deep nationalist affiliations with their respective 'motherlands', Greece and Turkey (Papadakis 2008). While GCs demanded and fought the British rule 
in name of Enosis ('union' with Greece), TCs reacted by supporting the partition (Taksim) of the island. Exacerbated by opposite political aims and reciprocal suspicion and fears, in December 1963 Cyprus experienced its most intense bloody inter-communal violence. The following year, the United Nations deployed a peacekeeping force (UNFICYP) to prevent further fighting. Among the measures adopted, there was also the establishment of the Green Line, a de facto border separating the two communities in Nicosia. Being the main target of the 1963 violence, the TCs came to live in selfconstituted territorial enclaves (Akçalı 2009). The gradual return to inter-communal working and commercial life in the late 1960s was, however, interrupted abruptly in July 1974 when, supported by the Greek military junta, a right-wing GC group deposed the President of the Republic of Cyprus and demanded Enosis (Papadakis 2005). This prompted the military intervention of Turkey and the actual partition of the island along a ceasefire line, again known as Green Line, this time running North-South through the whole island (Copeaux and Mauss-Copeaux 2006).

As attempts to find a solution to the partition failed, in 1983 the part of the island north of the Green Line declared independence with the name of Turkish Republic of Northern Cyprus (TRNC), which until today has only been recognized by Turkey and put under embargo by the rest of the international community.

Despite ongoing negotiations among the leaders of the two political entities and the support of the UN to favour the reconciliation of the parties through various bi-communal initiatives, over the last thirty years or so no significant steps have been made towards the creation of the bi-zonal and bi-communal federal state, which was the solution agreed on by the two parties in 1977 (Akçalı and Antonsich 2009). 
A great chance to solve the Cyprus Problem came in April 2004, when the UN Annan Plan for the reunification of the island was put under referendum (Heraclides 2004; Sözen and Özersay 2007). This happened while both GCs and TCs were negotiating Cyprus's membership to the European Union. Hoping maybe for the end of the embargo and a new future in the EU, 65 percent of TCs voted in favour of the reunification proposed by the Annan Plan. On the contrary, as the EU membership of the RoC was already secured and also due to the dissatisfaction with some of the concessions made to the other side by the Annan Plan, 76 percent of GCs voted against the reunification (Papadakis 2005). Consequently, only the RoC joined the EU, but in a rather contradictory move EU citizenship was also extended to TCs.

In summer 2008, a new negotiation round started, but so far the parties have failed to reach any comprehensive agreement towards the reunification of the island. This somewhat reflects the sceptical attitudes of the majority of TCs and GCs, who, while remaining open to inter-communal negotiations, disagree on the actual measures to be adopted (Cyprus2105 2011). More recently, the RoC's initiative to start oil and gas drilling in the eastern Mediterranean Sea has led to a tense diplomatic row with Turkey over the boundaries of RoC's Exclusive Economic Zone, further complicating the negotiation process on the island's future. This is also accentuated by the continuing Anglo-American presence in Cyprus which, besides Greece and Turkey, also have a geopolitical interest in the island, having played an important role in the events which led to its partition (Hitchens 1984; Joseph 1997) and still firmly quartered in the British sovereign base areas of Akrotiri and Dhekelia. 


\section{The Buffer Zone as a 'space of exception'}

The BZ, also known as Green Line, is an area which extends north-south for approximately 180 kilometres and covers about 3 percent of Cyprus's land area. The width of this strip varies considerably, from only a few meters in Nicosia to a few kilometres in some rural areas. Its northern and southern limits do not constitute state borders, but only ceasefire lines, recorded by the UNFICYP on 16 August 1974, the day in which the belligerents stopped fighting. ${ }^{4}$

Despite being labelled by the GCs as 'Dead Zone', the BZ actually hosts several villages or special areas, where more than 10,000 people live and/or work. While the access to these areas is free to civilians, other parts of the BZ, included the one within Nicosia, require instead UNFICYP authorizations for civilian movement and/or activities.

Since April 2003, a number of crossing points, also within the historic centre of Nicosia (Ledra street), have opened, thus allowing the free flow of GCs and TCs, which until then was forbidden due to the resistance of TC authorities (Copeaux and MaussCopeaux 2006; Peristianis and Mavris 2011).

The BZ has a distinctive juridical status. As recalled by Constantinou $(2008,156)$, the UN has indeed created over this area a true 'state of exception'. Constantinou uses this term somewhat differently from Agamben (2005). In the interpretation of the Italian philosopher, the state of exception is the "suspension of the juridical order" by the sovereign, who, following Carl Schmitt, is defined as "he who decides on the state of exception" (Agamben 2005, 1-4). Over recent years, Agamben's work has become rather 
popular. Among geographers, in particular, the focus has been on exploring the spatial forms of the state of exception: the camp (Minca 2005; Ek 2006; Bülent and Laustsen 2006), the border (Lynn Doty 2007; Salter 2008; Basaran 2008), the prison (Martin and Mitchelson 2009), extra-territorial spaces (Gregory 2006; Comaroff 2007), and inbetween spaces (Morris 2003).

Various authors have also suggested that in the present world the exception has been normalized or re-worked into a sort of biopolitical nomos (Minca 2006). Each of us can become homo sacer and thus being exposed and abandoned to violence (Gregory 2006).

While largely sharing these views, Constantinou (2008) aims to enlarge the scope of the conversation by re-reading the 'state of exception' in light of post-colonialism. He observes that very often the 'de-colonized world' was never given the choice between normality and exception, but only between different states of exception (Constantinou 2008, 147). "For the postcolonial state - writes Constantinou (ibid.) - exceptionality as constricted sovereignty has often been systemic and endemic, underscoring exceptionalism not as a mere by-product of governmental 'decrees of necessity', but as a foundational act that was imposed and neatly combined with emancipatory pretensions." In this sense, the state of exception is no longer a condition produced by the sovereign over its own territory, but by external powers over the new 'b-ordered' territory of the post-colonial state.

Constantinou offers an original reading of Cyprus's contemporary history as one made of multiple states of exception. Among them, Constantinou also includes the BZ. For him, its exceptionality emerges clearly from one of the periodical UN Secretary 
General's Reports (S/12253 - 1976), which stated "that neither side can exercise authority or jurisdiction beyond its own forward military lines" (Constantinou 2008, 156). The BZ is therefore a space of exception since on this space the juridical order of both $\mathrm{RoC}$ and TRNC is suspended. Within the BZ, the sovereign is the $\mathrm{UN}$ - a sovereign which, ironically, has neither territory nor people, but which, exceptionally, can claim both authority and jurisdiction over the BZ.

At the same time, though, Constantinou refers to the existence of 'exceptions to the exception'. A state of exception can indeed trigger counter-exceptions, "rationalized as resistance or liberation, or as attempts at normalization" (Constatinou 2008, 146). Within this perspective, a spiral of exceptionalisms is activated, which can provide interstices of manoeuvre for various actors, territorial and not, aimed at nullifying the norm and/or its exception.

It is within this juridical and theoretical context that I locate my attempt to map the terrain and practices of resistance of the OBZ movement. While the 'border' in Cyprus has long been contested - most notably by the bi-communal and feminist-inspired 'Hands Across the Divide' group (Cockburn, 2004) - to my best knowledge, no other movement in the world has chosen to dispute the border 'from within'. It is exactly the geopolitical uniqueness of this terrain of resistance which makes OBZ worth being investigated.

\section{OccupyBufferZone}


The specific site chosen by the OBZ movement is a symbolically very dense space. For the GCs, the BZ represents a 'Dead Zone' (Papadakis 2008). Since 1974, the area has been indeed left untouched; until 2003, crossing was not permitted and those GCs who tried to violate this space were killed by Turkish soldiers. Mourning the loss of their relatives, villages and properties, GCs have dotted their side of the BZ in Nicosia with several monuments, plaques, photos and banners conveying feelings of both sorrow and resentment and calling for a right to return (Figure 2). On the northern side of the BZ, TCs have not equally memorialized their landscape, although this does not mean that they have not gone through the same sufferance caused by inter-ethnic violence (Bryant 2010). On the contrary, at the Ledra Palace's crossing, a more imposing check-point surmounted by the sign 'TRNC Forever' suggests that the BZ might be perceived by some TCs as a sort of protection (Figure 3) (Peristianis and Mavris 2011, 151). ${ }^{5}$

In this sense, the BZ is clearly a site where the 'performance of the border' (Green 2010) is associated with various re-enacting of memories, a representational space filled with often contrasting discourses, forces, beliefs, and symbols, which, for this very reason, transforms that space into a terrain of contestation and potential resistance to spatially and culturally contextualized powers (Routledge 1994, 560-1).

Over time, the BZ has also been used, thanks also to the initiative of the UNDP, as a site to organize bi-communal events (Akçalı and Antonsich 2009). Recently, in May 2011, RoC and TRNC presidents jointly opened in the BZ in Nicosia the 'Home for cooperation', whose aim is to mutually discover the two different versions of history taught on the island. ${ }^{6}$ This latest bi-communal initiative, along with the fact that some NGOs and foreign cultural institutions (Goethe Institute; Fulbright Program) have chosen to 
open their offices in the BZ, clearly speak of the BZ as a neutral space and, as such, a space of encounter. Yet, these initiatives implicitly confirm what they want to overcome, namely the existence of two distinct territories, two separated communities which indeed only meet at the border.

The OBZ movement defies this bi-communal approach, claiming that it exactly perpetuates a divisive logic. As Green $(2010,261)$ aptly remembers, borders indeed generate the differences that they mark, rather than simply reflecting them. Accordingly, the OBZ movement challenges the idea of border tout court. 'Borders are scars upon the Earth's body', 'This is nationalism. No borders', 'UNBuffer Us' are some of the slogans exhibited by the movement (Figure 4). ${ }^{7}$ Such a 'no-borders' discourse clearly speaks the language of anti-geopolitics activism (Routledge 1994), as it tries to achieve emancipatory change through conscious opposition to state-centred notions of power and identity, as well as global capitalism. The OBZ activists aim indeed "to raise awareness of how the Cyprus Problem is but one of many symptoms of an unhealthy global system": "The Cyprus Problem is a world problem, as are all problems [...] if we don't change the world, we will forever be vulnerable to the consequences of a system that necessitates, rewards and promotes acts of aggression, greed and dishonesty. We cannot possibly hope to change an island in a world as unwell as this one, we could only ever hope to change the world." "In an interesting move from the local to the global, the OBZ movement therefore presents itself as one of the many Occupy movements world-wide, merging a context-specific demand (Cyprus's reunification) with anti-capital, anti-state and eco-friendly stances. 
The OBZ activists are clearly aware of the exception to the norm associated with the BZ. As mentioned in one of their Facebook posts, dated 03/12/2011, "There are many Cypriots from the North staying at the camp tonight to boycott what they feel will be a fixed census tomorrow. This is legal as you are "out of the country." This is an invitation to join them. Bring your tents!" Choosing to locate their resistance within a space of exception allows for new empowering practices, which defies b-ordering regimes of state power. As aptly portrayed by Sinan Dirlik, in a news article praised by the OBZ activists, in the BZ notions like nationality, religion, and authority are suspended: "Mihalis is a Greek. Turgut is a Turk. But in the buffer zone, Mihalis is no longer a Greek, nor is Turgut a Turk." ${ }^{10}$ The exception is deliberately played out by the activists to organize their resistance. It also closely resonates with their 'no-border' discourse. It is indeed the fact that the BZ is a site of exception to the norm which b-orders space and people on both sides of the border which allows for transgressing that very norm. And it is also what allows them to put forward their project for a reunified island, where, in terms of identity politics, the 'bi-communal' is substituted with 'multi-communal': "Here we have Armenians, Latins, Maronites, Cypriots who speak Turkish and Greek [...] so we can't say two communities $[\ldots]$ To be a Cypriot is a multi-cultural thing". ${ }^{11}$

The occupation of the BZ is also revealing of the importance of bodies in practices of resistance (Pile and Keith 1997). As it is well known, social networks have played a key role in mobilizing the 'Arab Spring' and the Occupy movements world wide, being crucial also in rallying support for the OBZ movement. Yet, the OBZ activists show the limits of 'virtual' revolutions: "So you clicked 'Like', but revolutions don't happen clicking away on Facebook, that's step 1. Step 2 is to show your face tomorrow. 6pm 
Lidra Street Crossing south side, where we will gather before occupying the buffer zone [...]" ${ }^{12}$ However crucial social networks might be today, they do not replace the need for real bodies which engage in earthy practices of resistance. "We need people to come and make things happen in this space [...]. We need new people sleeping here to change the dynamics again and offer new energy, ideas and HANDS! We need participation". ${ }^{13}$

Sitting comfortably in front of a laptop and participating remotely cannot be a substitute for bodily, emplaced practices of resistance (Pile 1997). Through the bodily occupation of the $\mathrm{BZ}$ and the mundane activities associated with that occupation (eating, drinking, sleeping, singing, discussing, etc.), the activists broke somewhat a 'taboo' in Cypriot society, as observed by a local GC newspaper. ${ }^{14}$ Existing for almost forty years, the BZ has indeed become part of Cyprus's 'ordinary landscape' (Meinig 1979), which as such goes unnoticed, having become 'normal' and, therefore, invisible (Demetriou 2007). The occupation of the BZ, by being itself an extra-ordinary act, brings again to visibility the exceptionality of the condition in which Cypriots live. Filling this exceptional space with ordinary practices is a form of resistance which, like the artistic interventions on the border recounted by Amoore and Hall (2010), interrupts sequences, habits, and rituals of living and re-producing, also for security purposes, the border(zone), while opening up space for alternative political projects.

Following a long series of dissuasive measures put forward by TC and GC authorities, on April $6^{\text {th }}$, 2012, a GC anti-terrorist unit and drugs squad raided the OBZ camp, beating and arresting several activists. ${ }^{15}$ The GC police justified the raid on a search warrant after information that drugs were in a building illegally occupied by OBZ activists. Although officially the UNFICYP's stance towards the OBZ movement had 
spanned from an original sympathy to a more pragmatic toleration, ${ }^{16}$ de facto they sided with both the TC and GC authorities. Being itself a political actor, exposed to the pressures of RoC and TRNC authorities (Grundy-Warr 1994), the UNFICYP did not protest the violent restoration of the 'norm' by the GC police, officially claiming that the raided building was not located in the BZ. ${ }^{17}$ As Constantinou (2008) puts it, any exception is associated with counter-exceptions, giving way to a spiral of exceptionalisms where different dynamics of power are at play, which defy the simple binary logic of oppressor and oppressed often associated with a mainstream reading of Agamben's.

Severely hit by the police raid and strained by both the fatigue of six-month occupation and internal frictions, the OBZ activists finally lifted their camp at the end of May 2012. "We are now taking a pause; the eviction affected people psychology, so we need to recover; but the group is still there and so is the BZ; we are just taking time to see what to do next; OBZ is not over, it will never be."18

\section{Conclusions}

Transgression is often the preferred form of resistance practiced by social movements (Foust 2010). By escaping the discipline of boundary-policing authorities and violating an 'off-limit' space, the OBZ movement also engages in performative practices of transgression which call for social, economic and political change. Its experience, I would argue, allows for a series of considerations which can illuminate further the notion of terrain of resistance. First, the OBZ movement offers evidence for going beyond a simple, binary logic which often characterizes how the notion of exception has been 
operationalized. When located within the post-colonial context of Cyprus, the exception takes on new meanings, as the space where the norm is suspended becomes a terrain of resistance which challenges that very norm. The BZ is indeed both the object of contestation and the condition which allows for that contestation to take place. No longer the space where life becomes 'bare life' (Agamben 1998), exposed to violence and death, the exception is where the OBZ activists take refuge in. Second, confirming the insights from previous literature (Pile 1997), the OBZ experience reasserts the importance of emplaced and embodied resistance. However relevant online social networks might be today, resistance still happens both in places and through bodies. Third, and related to this point, emplaced resistance matters also because the alternative use of space made by the activists challenges the 'norm-alization' of space produced by the dominant power. Altering the everyday (non-)use of space as defined by a system of power is per se revolutionary. As space is imbued with power relations, any resistance to be successful should therefore aim at appropriating and making new spaces (Featherstone 2008; Pile 1997). Transforming the BZ in an undivided space where Cypriots could live together questions the existence of two distinct territories and their respective political powers, thus triggering a violent act of re-territorialisation/re-normalisation. This elicits a fourth consideration, which also helps refining Agamben's theory: any exception is associated with counter-exceptions, which can be exploited by both the territorialising/normalising power (as in the case of the GC police raid) and those who oppose it. Given the eviction of the OBZ camp as well as of other Occupy camps world-wide, a final consideration, in the form of an interrogative, should come forward: 'what space is left today for resistance?' This question clearly echoes the interrogative by Don Mitchell (2003) about 
socio-spatial justice: who has access to space, why, and at what conditions? One way to answer this question is to recover De Certeau's (1984) famous distinction between strategy and tactics, concluding that resistance can always find a place in the ambiguities and opacities of power's technocratic transparency. This is also Thrift's (1997) answer, which pays indeed attention to everyday, ordinary, less-than-heroic acts of resistance (Thrift 1997). Another, complementary way to look at the same question is to reframe it in a less either-or logic. Success and failure of resistances can neither be easily defined nor measured. As Routledge $(1997,69)$ suggests, resistances are fluid processes, whose emergence and dissolution cannot be fixed at points in time. Similarly, resistance and power do not exist as separated categories, being in fact closely entangled in ambiguous relations (Sharp et al. 2000) - something which should warn about the risk of romanticizing the emancipatory and progressive potential of any resistance (Moore 1997). The OBZ movement offers evidence to support all these perspectives, while confirming at the same time Routledge's $(1997,83)$ intuition about the impracticality of capturing resistance within an overarching theory, as resistance will always be dependent on the contingency of the chosen terrains.

\section{References}

Agamben G 1998 Homo Sacer Stanford University Press, Stanford.

Agamben G 2005 State of Exception Chicago University Press, Chicago.

Akçalı E 2009 Chypre L'Harmattan, Paris. 
Akçali E and Antonsich M 2009 'Nature knows no boundaries': a critical reading of

UNDP environmental peace-making in Cyprus Annals of the Association of American

Geographers 99 940-947.

Amoore L and Hall A 2010 Border Theatre: On the arts of security and resistance Cultural Geographies 17 299-319.

Basaran T 2008 Security, law, borders: spaces of exclusion International Political Sociology 2 339-354

Bryant R 2010 The Past in Pieces Penn Press, Philadelphia.

Bryant R 2012 Partitions of Memory Comparative Studies in Society and History 54(2) $332-360$.

Bülent D and Laustsen CB 2006 The camp Geografiska Annaler Series B 88 443-452.

Comaroff J 2007 Terror and Territory Public Culture 19 381-405.

Constantinou CM 2008 On the Cypriot states of exception International Political Sociology 2 145-164.

Copeaux E and Mauss-Copeaux C 2006 Dividing past and present in Brandell I ed State frontiers. I.B. Tauris, London 33-51.

Cyprus2015 $20113^{\text {rd }}$ public opinion poll (http://www.cyprus2015.org/) Accessed $20 / 12 / 2011$.

De Certeau M 1984 The Practice of Everyday Life University of California Press, Berkeley.

Demetriou $O 2007$ Freedom square: the unspoken of a divided city Hagar 7 1-17

Ek R 2006 Giorgio Agamben and the spatialities of the camp Geografiska Annaler Series B 88 363-386. 
Featherstone D 2008 Resistance, space and political identities Wiley-Blackwell,

Chichester.

Foust CR 2010 Transgression as a mode of resistance Lexington Books, Plymouth.

Green S 2010 Performing border in the Aegean Journal of Cultural Economy 3 261-278.

Gregory D 2006 The black flag Geografiska Annaler Series B 88 405-427.

Grundy-Warr C 1994 Toward a political geography of UN peacekeeping Geojournal 34 177-190

Heraclides A 2004 The Cyprus problem The Cyprus Review 16 37-54.

Hitchens C 1984 Cyprus London Quartet Books.

Joseph JS 1997 Cyprus London MacMillan.

Lynn Doty R 2007 States of exception on the Mexico-U.S. border International Political Sociology 1 113-137.

Martin L and Mitchelson M 2009 Geographies of detention and imprisonment Geography Compass 3 459-477.

Meinig DW 1979 The interpretation of ordinary landscapes Oxford University Press New York.

Minca C 2005 The return of the camp Progress in Human Geography 29 405-412.

Minca C 2006 Giorgio Agamben and the new biopolitical nomos Geografiska Annaler Series B 88 387-403.

Mitchell D 2003 The Right to the City Guilford Press, London.

Moore DS 1997 Remapping resistance in Pile S and Keith M eds 1997 Geographies of resistance Routledge, London 87-106.

Morris J C 2003 The spaces in between Refuge 21 51-62. 
Papadakis Y 2005 Locating the Cyprus Problem Macalester International 15 $81-98$.

Papadakis Y 2008 Echoes from the dead zone. I.B. Tauris, London.

Peristianis N and Mavris JC 2011 The "Green Line' of Cyprus: A contested boundary in flux in Wastl-Walter $\mathbf{D}$ ed The Ashgate Research Companion to Border Studies Ashgate, Farnham 143-170.

Pile S and Keith M eds 1997 Geographies of resistance Routledge, London.

Pile S 1997 Introduction in Pile S and Keith M eds 1997 Geographies of resistance Routledge, London 1-32.

Routledge P 1994 Backstreets, barricades, and blackouts: urban terrains of resistance in Nepal Environment and Planning D 12 559-578.

Routledge P 1996 Critical geopolitics and terrains of resistance Political Geography 6-7 509-531.

Routledge P 1997 A spatiality of resistances in Pile S and Keith M eds Geographies of resistance Routledge, London 68-86.

Routledge P 1998 Introduction in Ó Tuathail G, Dalby $\mathbf{S}$ and Routledge $\mathbf{P}$ eds The Geopolitics Reader Routledge, London 245-255.

Routledge P and Cumbers A 2009 Global justice networks Manchester University Press, Manchester.

Sharp J et al. 2000 Entanglements of Power Routledge, London.

Sözen A and Özersay K 2007 The Annan Plan: State succession or continuity Middle Eastern Studies 43 125-141.

Salter M B 2008 When the exception becomes the rule Citizenship Studies 
12 365-380.

Sparke M 2008 Political geographies of globalization III Progress in Human

Geography 32 423-440.

Thrift N 1997 The still point in Pile S and Keith M eds Geographies of resistance Routledge, London 124-151.

Figure 1. Map of Old Nicosia showing the border crossings (source: Nicosia Master Plan Archive, edited. Scale 1:10,000)

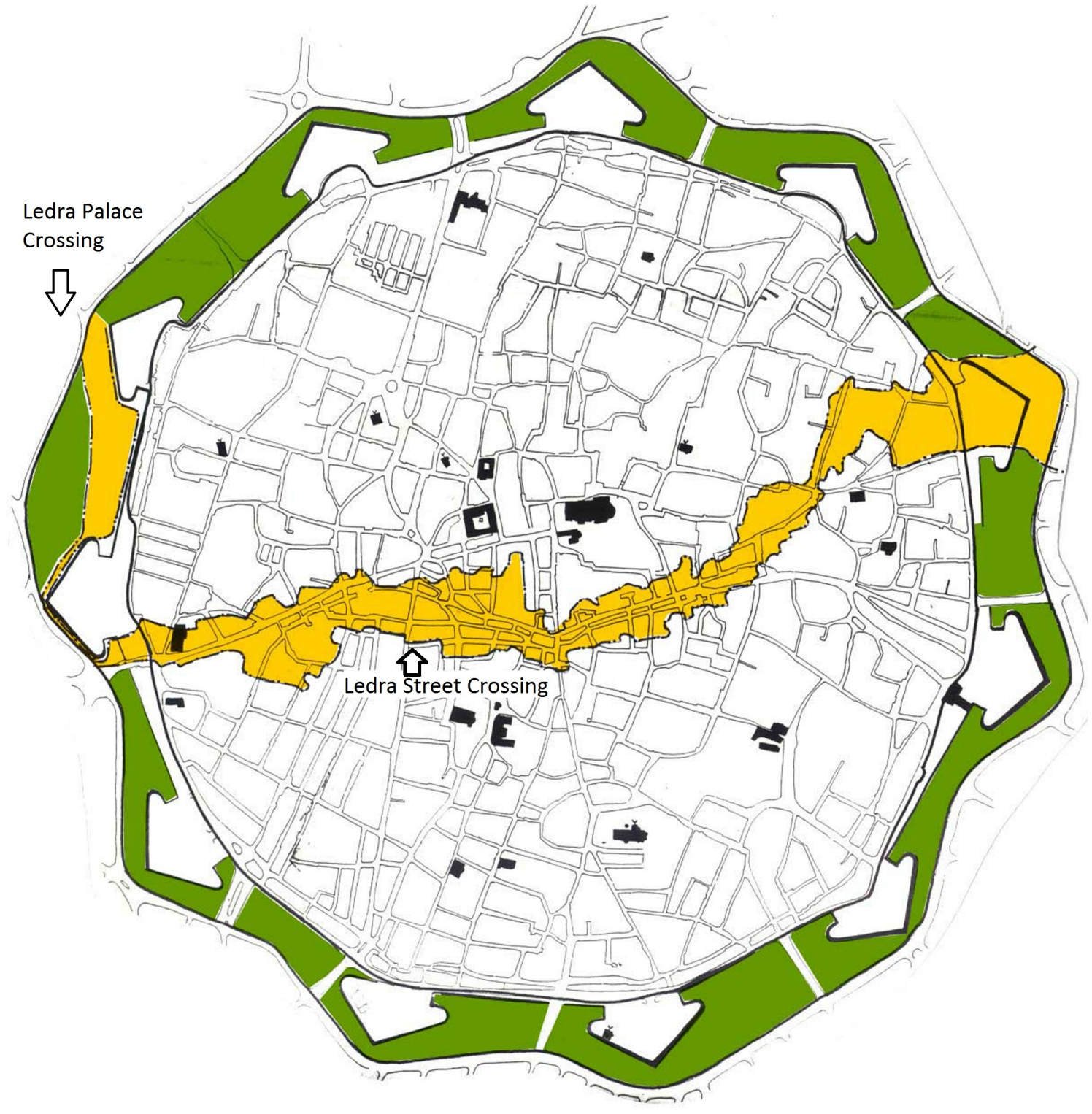


Figure 2. Nicosia. Memorializing the Greek Cypriot border landscape (Author's photo)

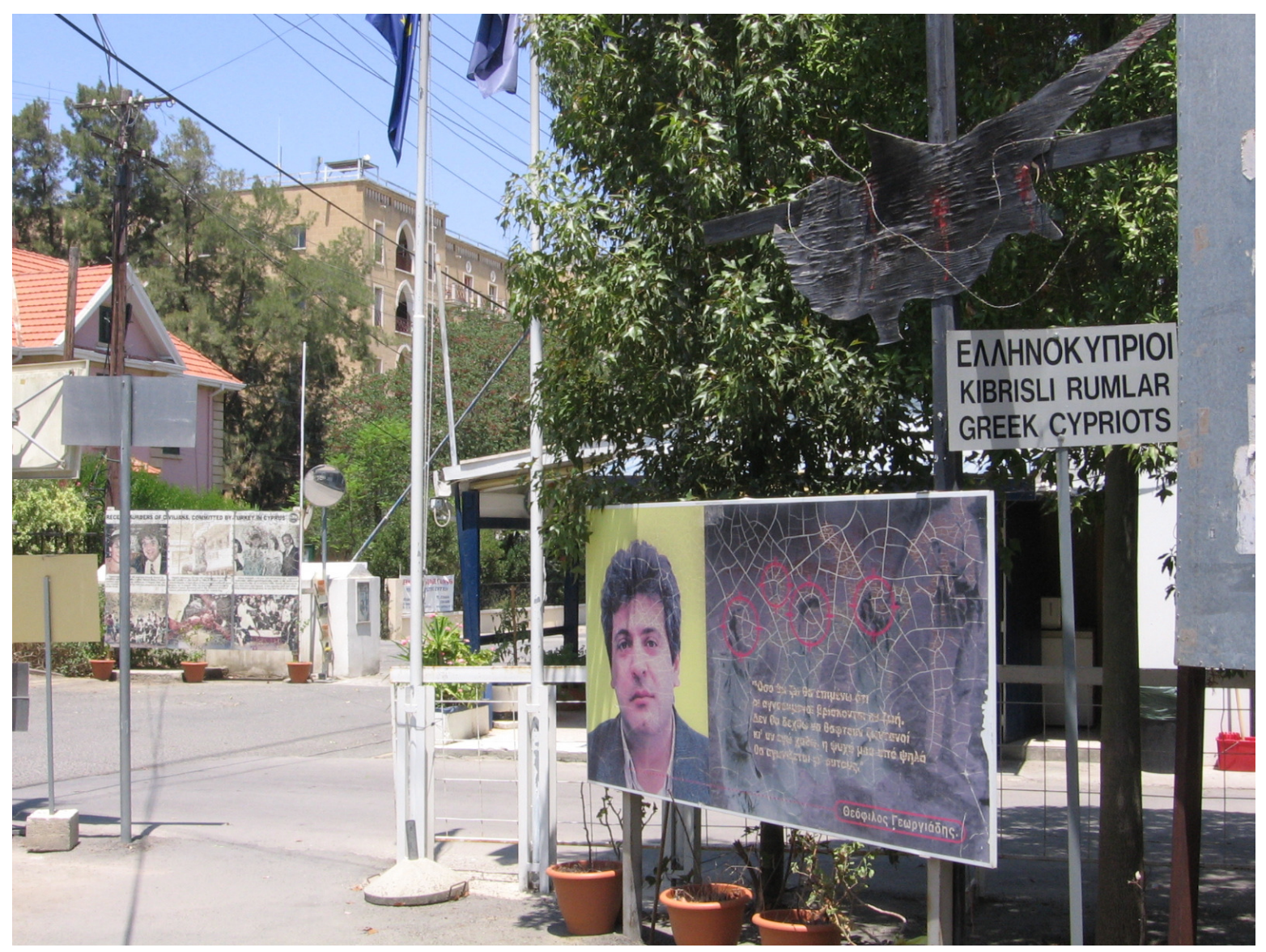


Figure 3. Nicosia. The TRNC check-point at Ledra Palace crossing (Author's photo)

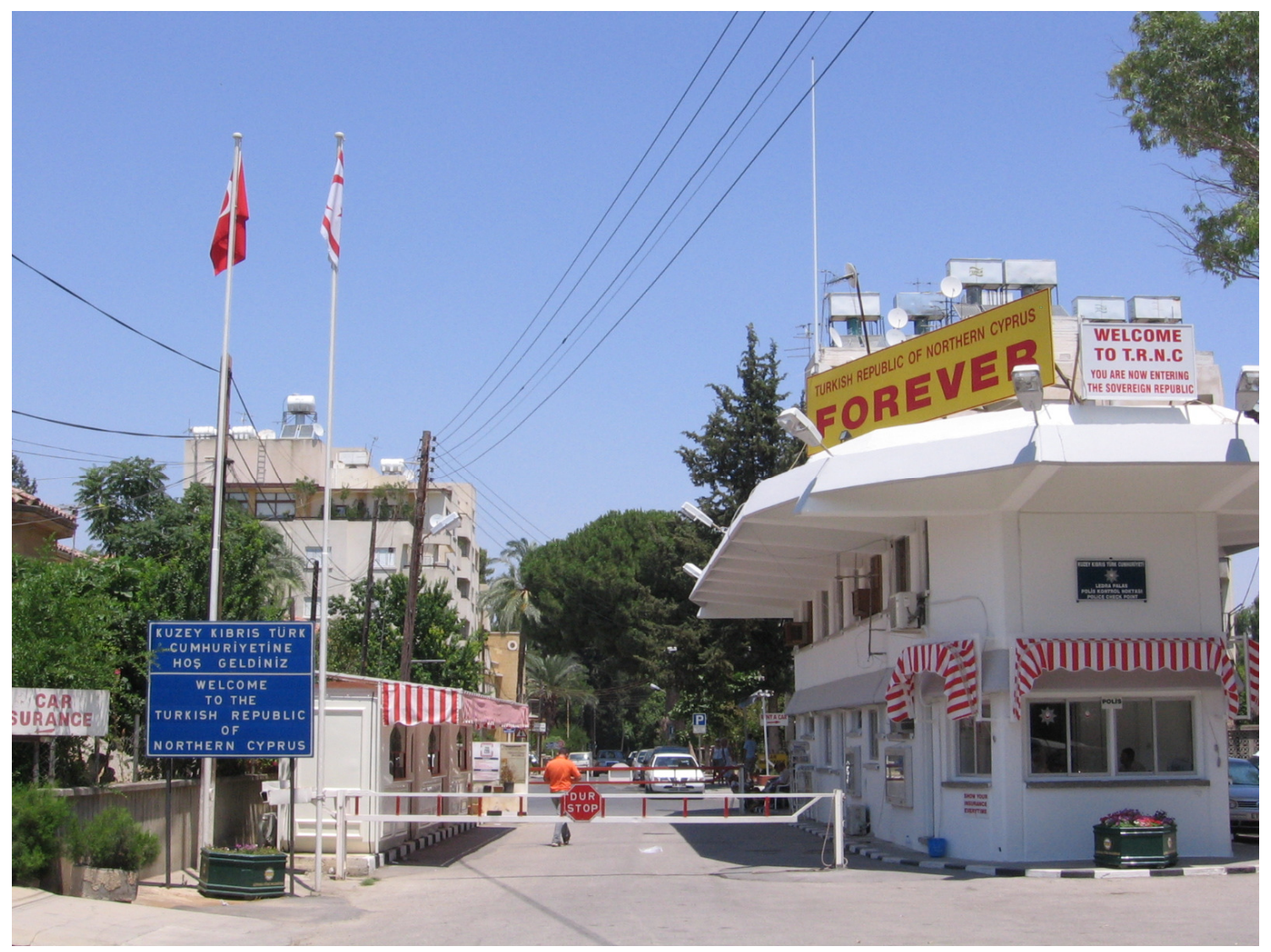


Figure 4. OBZ movement: 'No-borders' slogans (Mihalis Eleftheriou's photo)

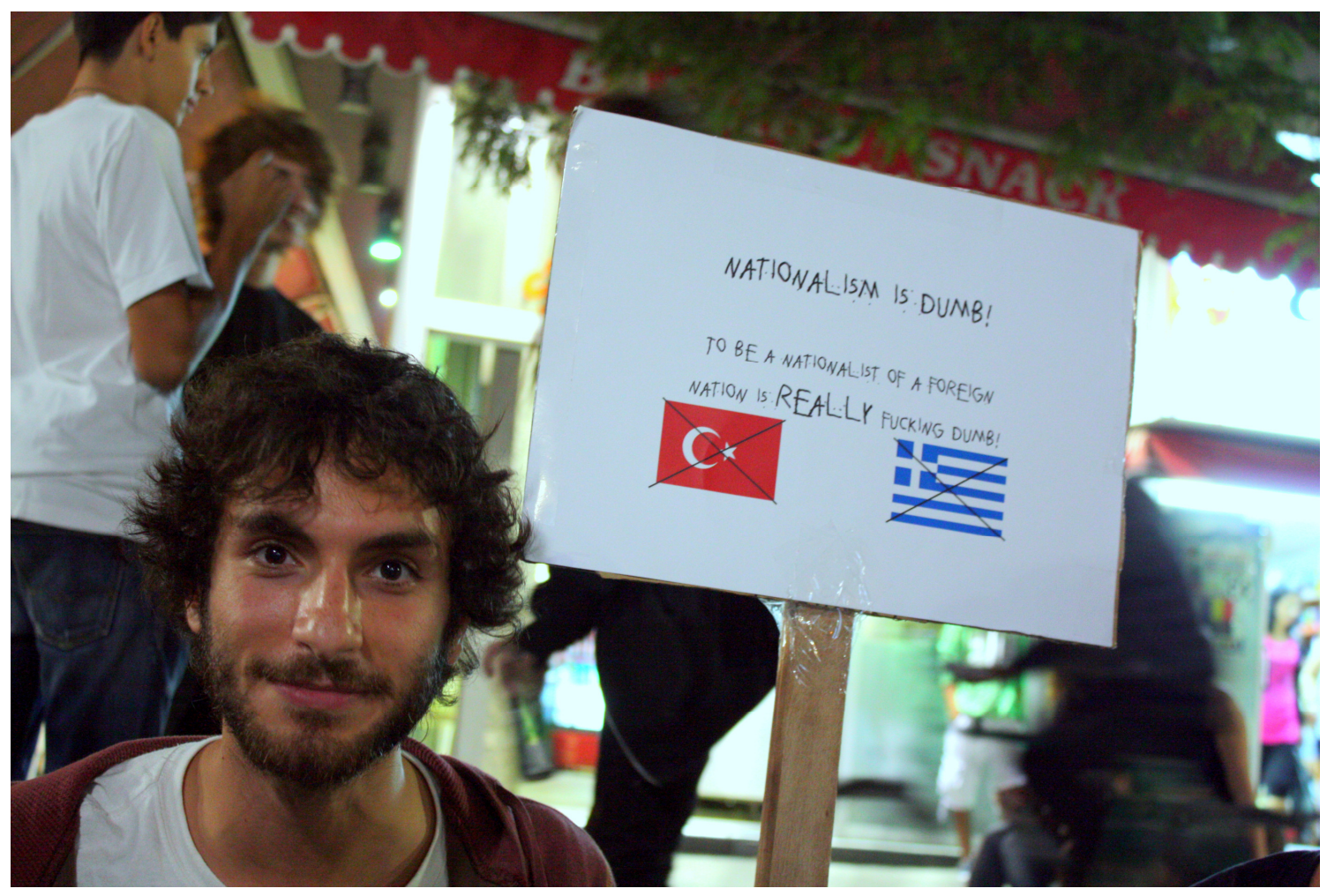

\footnotetext{
${ }^{1}$ Footage of the first day this protest is available on the movement's webpage:

http://occupythebufferzone.wordpress.com/videos/

${ }^{2}$ OBZ has a website (http://occupythebufferzone.wordpress.com/), a Facebook page (http://www.facebook.com/OccupyBufferZone) and can also be followed on Twitter (http://twitter.com/OccupyBufferZ). Besides various Cypriot newspapers, the voice of the activists has also been heard on Turkish TV channels (NTV) and newspapers (Hürriyet), and Greek newspapers (Kathimerini). Also international news agency (Reuters) and TVs (Al Jazeera and PressTV) have hosted the opinions of the activists (see a complete list on the OBZ website).
} 
${ }^{3}$ Methodologically, this section relies on qualitative content analysis carried out on the OBZ's websites, supported by personal communications with some of the most active members of the movement.

${ }^{4}$ UNFICYP 2011 Buffer Zone (http://www.unficyp.org/nqcontent.cfm?a_id=1592\&tt=graphic\&lang=11) Accessed 20/12/2011.

${ }^{5}$ The material and emotional memorialisation of the past, through which Cypriots read both the present and the future, is the focus of Bryant's (2010) book. In a more recent article, Bryant (2012) focuses on the metaphor of territorial partition as a 'wound', filled with both expectations of healing and anticipations of renewed suffering, thus offering a temporal understanding of the Cyprus Problem which complements the spatial interpretation proposed in the present article.

${ }^{6} \mathrm{H} 4 \mathrm{C}$ http://www.home4cooperation.info/ Accessed 15/02/2012.

${ }^{7}$ OBZ movement (http://occupythebufferzone.wordpress.com/slogans/) Accessed 16/01/2012.

${ }^{8}$ OBZ movement (https://www.facebook.com/note.php?note_id=10150476722881875) Accessed $16 / 012012$.

${ }^{9}$ OBZ movement (https://www.facebook.com/note.php?saved\&\&note_id=10150367103371875) Accessed $16 / 01 / 2012$

${ }^{10}$ The article (in Turkish) is available here:

http://reportare.com/index.php?option=com_content \&view=article\&id=81:ara-boelgenin-haylazcocuklar\&catid=38:a\&Itemid=79 
${ }^{11}$ Interview with Mihalis, OBZ activist:

http://reportare.com/index.php?option=com_content\&view=article\&id=81:ara-boelgenin-haylazcocuklar\&catid=38:a\&Itemid=79 Accessed 22/01/2012.

${ }^{12}$ OBZ movement (https://www.facebook.com/note.php?note_id=10150476722881875) Accessed $16 / 01 / 2012$.

${ }^{13}$ OBZ movement (https://www.facebook.com/note.php?note_id=10150476722881875) Accessed $16 / 01 / 2012$.

${ }^{14}$ Politis Katalipsi tis nekris zwnis: ena kinima geniete Politis 13 November 2011.

${ }^{15}$ Cyprus Mail 08/04/2012 http://www.cyprus-mail.com/cyprus/tensions-high-after-police-raid/20120408 Accessed 20/05/2012.

${ }^{16}$ Interview with Michel Bonnardeaux, UNFICYP spokesman, in Cyprus Mail (18/12/2011) available at http://www.cyprus-mail.com/occupy/buffer-zone-tent-protest-many-gripes/20111218 Accessed $25 / 01 / 2012$.

${ }^{17}$ See note 15 .

${ }^{18}$ Phone interview with an anonymous member of the OBZ movement (14/06/2012). 